\title{
Kepuasan Kerja sebagai Variabel Mediasi pada Pengaruh Ketidakjelasan Peran terhadap Kinerja Pegawai
}

\author{
Riska Susanti ${ }^{1 *}$, Rahmi Fahmy ${ }^{2}$ \\ ${ }^{1}$ Program Magister Manajemen, Fakultas Ekonomi, Universitas Andalas \\ ${ }^{2}$ Fakultas Ekonomi, Universitas Andalas \\ *riskasusanti74@gmail.com
}

\begin{abstract}
The purpose of this research is to analyze the effect of role ambiguity on employee performance mediated by job satisfaction. The population in this research is ASN employees (State Civil Servants) at the Puskesmas located in Padang Panjang City. Samples of this research are 108 people that have taken with a purposive sampling technique. The results of this research show: 1) Role ambiguity has a negative and significant effect on employee performance. 2) Role Ambiguity has a negative and significant effect on job satisfaction felt by employees, and 3) Job satisfaction has a positive and significant effect on employee performance, and 4) Job satisfaction acts as a mediating variable of the unclear role on employee performance
\end{abstract}

Keywords: Individual Performance, Job Satisfaction, Role Ambiguity

\section{PENDAHULUAN}

Perkembangan sumber daya manusia saat ini, tak bisa lepas dari dukungan pengetahuan dan ilmu yang dimiliki oleh manusia itu sendiri. Manusia merupakan modal bagi perusahaan. Untuk itu modal harus efektif bagi perusahaan sehingga diharapkan dapat menghasilkan return bagi perusahaan tersebut. Agar mencapai tujuan organisasi yang diharapkan, maka dibutuhkan teknologi yang selalu di upgrade serta sumber daya manusia yang mampu bersaing yang salah satunya dilakukan dengan cara memenuhi semua kebutuhan pegawainya. Kebutuhan pegawai tidaklah general namun diberikan sesuai dengan kapasitasnya masingmasing.

Fasilitas yang bertugas sebagai
pelayanan kesehatan dengan cara
melaksanakan upaya-upaya kesehatan
perseorangan serta masyarakat pada tingkat
pertama, dimana dalam hal ini lebih berfokus

pada upaya dalam mengenalkan dan mengantisipasi sebelum terjadi hal yang tidak diinginkan, demi tercapai posisi kesehatan masyarakat yang paling tinggi pada wilayah kerjanya yang dinamakan Pusat Kesehatan Masyarakat (Puskesmas) (Peraturan Menteri Kesehatan Nomor 75 Tahun 2014 tentang Pusat Kesehatan Masyarakat Pasal 1 Ayat 2, 2014). Dalam hal ini, untuk dapat menjalankan fungsi organisasi dengan baik, Puskesmas perlu memperhatikan keadaan fisik dan mental dari setiap pegawai agar mereka mampu menjalankan tugas dan kewajibannya di Puskesmas. Dengan kondisi yang stabil dari setiap pegawai akan menimbulkan kinerja yang baik dan efektif dari setiap pegawai. Beberapa faktor yang menunjukkan kinerja yang baik dan efektif yaitu kejelasan peran pegawai dan beban kerja yang tidak berlebihan. Dengan melakukan observasi lapangan dan melakukan wawancara singkat dengan pihak- 
pihak terkait, peneliti mendapat suatu keganjalan, dimana pegawai Puskesmas menjalankan tupoksi yang berlebih dari keseharusannya. Hal ini terjadi salah satunya karena kekurangan pegawai pada bagianbagian tertentu. Selain itu, juga terjadi ketidakjelasan peran yang dirasakan oleh pegawai karena tanggung jawabnya tidak tertera jelas. Karena ketidakjelasan peran dan beban kerja yang berlebih menyebabkan penurunan pada kepuasan kerja pegawai dan berujung pada rendahnya kinerja para pegawai tersebut.

\section{Kinerja}

Menurut Gibson et al. (2012), job performance adalah akumulasi dari segala sesuatu yang dilakukan dimana hal tersebutt berkaitan dengan tujuan organisasi, efektifitas dan efisiensi dari kinerja lainnya. Kinerja adalah suatu tindakan yang dilakukan oleh pegawai yang memiliki beberapa faktor yaitu kuantitas dan kualitas dari hasil kerja, tepat waktu dalam mengerjakan pekerjaan, kehadiran, dan kemampuan bekerja sama (Mathis \& Jackson, 2008).

Menurut Koopmans et al. (2014) dimensi untuk mengukur kinerja pegawai adalah dimensi task performance (kinerja tugas), contextual performance (kinerja kontekstual), dan counterproductive work behaviour (perilaku kerja kontra produktif).

\section{Ketidakjelasan Peran}

Ketidakjelasan peran dapat dikatakan sebagai salah satu faktor organisasi yang dapat mempengaruhi perilaku politik yang berarti perilaku pegawai tidak ditentukan secara jelas oleh organisasi. Maka diperlukan batasan yang lebih kecil untuk ruang lingkup dan tindakan politik dari pegawai (Robbins \& Judge, 2013).

Dimensi yang digunakan untuk mengukur ketidakjelasan peran adalah wewenang, tanggung jawab, kejelasan tujuan dan cakupan pekerjaan.

\section{Kepuasan Kerja}

Kepuasan kerja yaitu suatu sikap yang biasanya dirasakan oleh pegawai terhadap pekerjaan yang diemban dimana hal yang dirasakan dapat berupa seberapa besar ganjaran yang diterima yang dibandingkan dengan seberapa besar yang seharusnya ia terima (Robbins \& Judge, 2015). Dari setiap masing-masing pegawai pasti memiliki tingkat kepuasan kerja yang berbeda-beda, terdapat kepuasan kerja yang tinggi, sebaliknya juga terdapat kepuasan kerja yang rendah yang mampu memberikan efek yang berbeda pula.

Sikap yang dimiliki pegawai terhadap pekerjaannya ini merupakan hasil dari persepsi pegawai mengenai pekerjaan mereka yang didasarkan pada faktor lingkungan kerja seperti supervisor, kebijakan dan prosedur, rekan kerja, lingkungan kerja serta tunjungan tambahan yang pegawai terima (Gibson J. L., Ivancevich, Donnelly, \& Robert, 2012).

Untuk mengukur kepuasan kerja pegawai digunakan dimensi yaitu pay (pembayaran), promotion (peluang promosi), supervision (pengawasan), benefits (tunjangan), operating procedures (prosedur operasi), contingent rewards (penghargaan kontingensi), nature of work (sifat pekerjaan), co-workers (rekan kerja), dan communication (komunikasi).

\section{Pengaruh Ketidakjelasan Peran terhadap Kinerja Pegawai, Ketidakjelasan Peran terhadap Kepuasan Kerja, Kepuasan Kerja terhadap Kinerja Pegawai, dan Kepuasan Kerja berperan sebagai variabel mediasi antara Ketidakjelasan Peran terhadap Kinerja Pegawai}

Penelitian yang dilakukan oleh Khattak et al (2011) dengan judul "Impact of Role Ambiguity on Job Satisfaction: Mediating Role of Job Stress" menunjukkan bahwa ketidakjelasan peran memiliki hubungan negatif dengan kepuasan kerja, dan stres kerja berperan sebagai variabel mediasi. Hasil penelitian menunjukkan bahwa untuk meningkatkan kepuasan kerja maka stressor harus dikontrol, dengan itu maka stres kerja akan berkurang.

Penelitian yang dilakukan oleh Fanani dkk. (2008) menunjukkan bahwa ketidakjelasan peran memiliki pengaruh 
negatif terhadap kinerja karyawan. Dimana pengaruh negatif tersebut bersumber dari beberapa hal seperti timbulnya ketegangan dalam bekerja, terjadinya perpindahan pekerja seperti keluar dari perusahaan atau perpindahan posisi pekerjaan, dan penurunan kepuasan kerja yang mengakibatkan penurunan kinerja karyawan secara keseluruhan. Selain itu, ketidakjelasan peran juga mempengaruhi kinerja karyawan secara negatif. Hal tersebut berarti semakin besar ketidakjelasan peran yang dirasakan karyawan, maka semakin menurun pula kinerja dari karyawan. Sebaliknya, semakin kecil atau rendah ketidakjelasan peran yang dirasakan karyawan, maka kinerja dari pegawai tersebut akan semakin meningkat.

Palomino dan Frezatti (2016) juga melakukan penelitian yang berjudul "Role conflict, role ambiguity and job satisfaction: Perceptions of the Brazilian controllers" dengan sampel sebanyak 114 controller dan menggunakan analisis statistik deskriptif. Dari penelitiannya menghasilkan bahwa terdapat hubngan antara role ambiguity terhadap kepuasan kerja. Dari pengujian hipotesis menunjukkan terdapat pengaruh secara langsung dan signifikan antara role ambiguity terhadap kepuasan kerja karyawan yang dibuktikan dengan nilai $\mathrm{t}$ statistik sebesar 16,931.

Mariam (2009) juga melakukan penelitian dengan judul "Pengaruh Gaya Kepemimpinan dan Budaya Organisasi terhadap Kinerja Karyawan melalui Kepuasan Kerja Karyawan sebagai Variabel Intervening" yang mana penelitian ini dilakukan di PT. Asuransi Jasa Indonesia (Persero), dengan responden yang dijadikan sampel sebanyak 115 karyawan. Dari penelitian ini ditemukan bahwa budaya organisasi dan gaya kepemimpinan berpengaruh positif dan signifikan terhadap kepuasan kerja dalam meningkatkan kinerja karyawan. berikut:

Hipotesis pada penelitian ini sebagai

$\mathrm{H}_{1}$ : Ketidakjelasan peran memiliki pengaruh negatif dan signifikan terhadap kinerja pegawai.
$\mathrm{H}_{2}$ : Ketidakjelasan peran memiliki pengaruh negatif dan signifikan terhadap kepuasan kerja pegawai.

$\mathrm{H}_{3}$ : Kepuasan kerja memiliki pengaruh positif dan signifikan terhadap kinerja pegawai.

$\mathrm{H}_{4}$ : Kepuasan kerja berperan sebagai variabel mediasi antara ketidakjelasan peran terhadap kinerja pegawai.

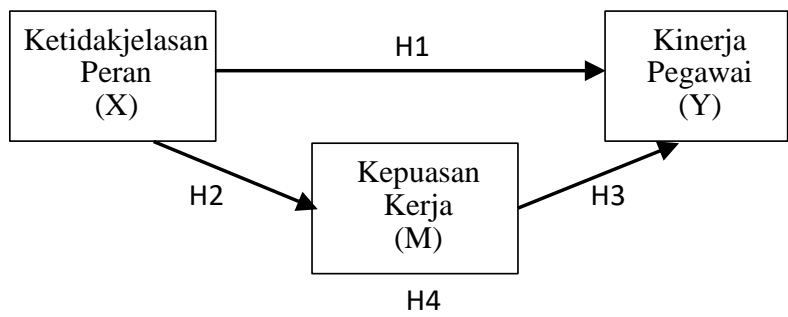

Gambar 1 : Kerangka Konsep Model Penelitian

\section{METODE \\ Jenis dan Sumber Data}

Data yang digunakan dalam penelitian ini berupa data kuantitatif yang berasal dari jawaban responden dari pengisian kuesioner yang disebarkan dan disajikan berdasarkan skala likert. Adapun sumber data priner diperoleh langsung dari kuesioner yang telah diberikan kepada masing-masing pegawai Puskesmas di Kota Padang Panjang sebagai objek penelitian.

\section{Populasi dan Sampel}

Populasi dalam penelitian ini adalah seluruh pegawai Puskesmas yang berada di Kota Padang Panjang dengan ukuran populasi sebesar 155 orang. Dimana jumlah populasi ini terdiri dari 4 Puskesmas di kota tersebut. Menurut tabel Sekaran dan Bougie (2016) untuk jumlah populasi sebesar 155 orang, maka jumlah sampel dalam penelitian ini berjumlah sebanyak 108 responden.

Desain pengambilan sampel yang penulis gunakan yaitu Nonprobability Sampling dimana elemen dari setiap populasi tidak memiliki probabilitas yang mengikat untuk dapat dipilih menjadi subjek sampel. Untuk teknik pengambilan sampling pada penelitian ini menggunakan teknik Purposive Sampling dimana sampel dikelompokkan 
pada tipe spesifik setiap orang yang mampu menyediakan informasi yang dibutuhkan oleh peneliti, hal tersebut bisa karena mungkin hanya mereka yang mempunyai informasi tersebut atau hanya mereka yang memenuhi kriteria yang sesuai dengan yang ditentukan oleh peneliti (Sekaran \& Bougie, 2016).

\section{Metode Analisis Data}

Metode analisis data yang digunakan dalam penelitian ini adalah dengan menggunakan metode SEM (Structural Equation Modeling). Adapun jenis Structure Equation Modeling (SEM) yang digunakan yaitu Smart PLS. Smart PLS adalah salah satu teknik non parametric statistika SEM berbasis varian yang tidak didasarkan banyak asumsi namun memiliki kemampuan untuk melakukan analisis jalur dengan variabel laten (tak terukur langsung).

Dalam metode PLS (Partial Least Square) teknik analisa yang dilakukan adalah analisis outer model untuk menentukan validitas data, melihat validitas diskriminan, menentukan apakah data sudah reliabel dan menentukan nilai cronbach's alpha. Selanjutnya melakukan analisis inner model dimana model ini diukur dengan melihat nilai atau besarnya R-square untuk variabel dependen, Stone-Geisser Qsquare test untuk memprediksi relevansi dan uji $\mathrm{t}$ serta signifikansi dari koefisien parameter jalur struktural. Tahapan selanjutnya yaitu uji hipotesis dan uji pengaruh mediasi.

Dari efek mediasi terlihat bagaimana hubungan yang ditimbulkan dari variabel independen dan dependen melalui variabel penghubung atau mediasi.

\section{HASIL DAN PEMBAHASAN Convergent Validity}

Tabel 1. Outer Loadings Variabel Ketidakjelasan Peran

\begin{tabular}{cccccc}
\hline Item & $\begin{array}{c}\text { Outer } \\
\text { Loading }\end{array}$ & Ket & Item & $\begin{array}{c}\text { Outer } \\
\text { Loading }\end{array}$ & Ket \\
\hline RA1 & 0,883 & Valid & RA8 & 0,845 & Valid \\
RA2 & 0,860 & Valid & RA9 & 0,908 & Valid \\
RA3 & 0,761 & Valid & RA10 & 0,682 & $\begin{array}{c}\text { Tidak } \\
\text { valid }\end{array}$
\end{tabular}

\begin{tabular}{cccccc}
\hline Item & $\begin{array}{c}\text { Outer } \\
\text { Loading }\end{array}$ & Ket & Item & $\begin{array}{c}\text { Outer } \\
\text { Loading }\end{array}$ & Ket \\
\hline RA4 & 0,760 & Valid & RA11 & 0,964 & Valid \\
RA5 & 0,873 & Valid & RA12 & 0,817 & Valid \\
RA6 & 0,965 & Valid & RA13 & 0,940 & Valid \\
RA7 & 0,852 & Valid & RA14 & 0,903 & Valid \\
\hline \multicolumn{5}{l}{ Sumber: Hasil Olahan SmartPLS 3.0, 2019 }
\end{tabular}

Tabel 1 menunjukkan bahwa hampir semua nilai outer loadings dari masingmasing item pernyataan ketidakjelasan peran lebih dari 0.70 yang berarti instrumen valid kecuali item pertanyaan nomor 10 yang menunjukkan instrumen tidak valid karena memiliki nilai kurang dari 0,70 .

Tabel 2. Outer Loadings Variabel Kepuasan Kerja

\begin{tabular}{cccccc}
\hline Item & $\begin{array}{c}\text { Outer } \\
\text { Loading }\end{array}$ & Ket & Item & $\begin{array}{c}\text { Outer } \\
\text { Loading }\end{array}$ & Ket \\
\hline KK1 & 0,760 & Valid & KK19 & 0,231 & $\begin{array}{c}\text { Tidak } \\
\text { valid }\end{array}$ \\
KK2 & 0,656 & $\begin{array}{c}\text { Tidak } \\
\text { valid }\end{array}$ & KK20 & $-0,113$ & $\begin{array}{c}\text { Tidak } \\
\text { valid }\end{array}$ \\
KK3 & 0,767 & Valid & KK21 & $-0,063$ & $\begin{array}{c}\text { Tidak } \\
\text { valid }\end{array}$ \\
KK4 & 0,847 & Valid & KK22 & 1,037 & Valid \\
KK5 & 0,706 & Valid & KK23 & 0,777 & Valid \\
KK6 & 0,934 & Valid & KK24 & 0,262 & $\begin{array}{c}\text { Tidak } \\
\text { valid }\end{array}$ \\
KK7 & 0,893 & Valid & KK25 & 0,074 & $\begin{array}{c}\text { Tidak } \\
\text { valid }\end{array}$ \\
KK8 & 0,815 & Valid & KK26 & 0,179 & $\begin{array}{c}\text { Tidak } \\
\text { valid }\end{array}$ \\
KK9 & 0,853 & Valid & KK27 & 0,727 & Valid \\
KK10 & 0,839 & Valid & KK28 & 0,652 & $\begin{array}{c}\text { Tidak } \\
\text { valid }\end{array}$ \\
KK11 & 0,315 & Tidak & KK29 & 0,911 & Valid \\
KK12 & 0,302 & $\begin{array}{c}\text { Tidak } \\
\text { valid }\end{array}$ & KK30 & 0,909 & Valid \\
KK13 & 0,784 & Valid & KK31 & 0,177 & $\begin{array}{c}\text { Tidak } \\
\text { valid }\end{array}$ \\
KK14 & 0,528 & $\begin{array}{c}\text { Tidak } \\
\text { valid }\end{array}$ & KK32 & 0,220 & $\begin{array}{c}\text { Tidak } \\
\text { valid }\end{array}$ \\
KK15 & 0,429 & $\begin{array}{c}\text { Tidak } \\
\text { valid }\end{array}$ & KK33 & 0,077 & $\begin{array}{c}\text { Tidak } \\
\text { valid }\end{array}$ \\
KK16 & 0,738 & Valid & KK34 & 0,990 & Valid \\
KK17 & 0,828 & Valid & KK35 & 0,799 & $\begin{array}{c}\text { Valid } \\
\text { Tidak }\end{array}$ \\
Sumber $:$ Hasil Olahan SmartPLS 3.0, 2019 & Valid & KK36 & 0,692 & valid \\
\hline
\end{tabular}


Tabel 2 memperlihatkan bahwa sebagian besar nilai dari outer loadings masing-masing item pernyataan kepuasan kerja lebih dari 0,70 yang berarti instrumen valid, kecuali item pertanyaan nomor 2,11 , $12,14,15,19,20,21,24,25,26,28,31,32,33$, 36 yang menunjukkan instrumen tidak valid karena memilik nilai kurang dari 0,70.

Tabel 3. Outer Loadings Variabel Kinerja Pegawai

\begin{tabular}{cccccc}
\hline Item & $\begin{array}{c}\text { Outer } \\
\text { Loading }\end{array}$ & Ket & Item & $\begin{array}{c}\text { Outer } \\
\text { Loading }\end{array}$ & Ket \\
\hline KI1 & 0,855 & Valid & KI10 & 0,868 & Valid \\
KI2 & 0,925 & Valid & KI11 & 0,874 & Valid \\
KI3 & 0,879 & Valid & KI12 & 0,838 & Valid \\
KI4 & 0,854 & Valid & KI13 & 0,853 & Valid \\
KI5 & 0,875 & Valid & KI14 & 0,942 & Valid \\
KI6 & 0,606 & Tidak & KI15 & 0,911 & Valid \\
KI7 & 0,851 & Valid & KI16 & 0,824 & Valid \\
KI8 & 0,838 & Valid & KI17 & 0,798 & Valid \\
KI9 & 0,888 & Valid & KI18 & 0,832 & Valid \\
\hline
\end{tabular}

Sumber : Hasil Olahan SmartPLS 3.0, 2019

Tabel 3 memperlihatkan bahwa nilai outer loadings dari masing-masing item pernyataan kinerja pegawai lebih dari 0.70 yang berarti instrumen valid kecuali item pertanyaan nomor 6 yang menunjukkan instrumen tidak valid karena memilik nilai kurang dari 0,70. Berdasarkan tabel 1, 2 dan 3 maka terbukti tidak semua outer loadings diatas 0.70 . Sehingga pertanyaan yang tidak valid akan dibuang dari model. Berdasarkan hasil olahan outer loading diatas, maka dapat disimpulkan bahwa konstruk dari penelitian mempunyai convergent validity yang baik, karena sebagian besar nilai outer loading lebih dari 0,70 .

\section{Composite Reliability}

Tabel 4. Composite Reliability Variabel

\begin{tabular}{lr}
\hline \multicolumn{1}{c}{ Variabel } & $\begin{array}{c}\text { Composite } \\
\text { Reliability }\end{array}$ \\
\hline Kepuasan Kerja & 0,980 \\
Ketidakjelasan Peran & 0,976 \\
Kinerja Pegawai & 0,981 \\
\hline Sumber : Hasil Olahan SmartPLS 3.0, 2019
\end{tabular}

Composite reliability dapat dinyatakan baik jika nilainya $\geq 0.70$. Nilai dari Composite reliability untuk semua variabel pada tabel 4 terlihat bahwa lebih besar dari 0.70 sehingga model variabel memiliki realibilitas yang baik.

\section{Cronbach's Alpha}

Tabel 5. Cronbach's alpha Variabel

\begin{tabular}{lrc}
\hline \multicolumn{1}{c}{ Variabel } & $\begin{array}{c}\text { Cronbach's } \\
\text { alpha }\end{array}$ & Keterangan \\
\hline Kepuasan Kerja & 0,980 & Reliable \\
Ketidakjelasan Peran & 0,976 & Reliable \\
Kinerja Pegawai & 0,981 & Reliable \\
\hline Sumber : Hasil Olahan SmartPLS 3.0, 2019 \\
\multicolumn{3}{c}{ Nilai cronbach's alpha pada tabel 5 } \\
berada pada nilai lebih besar dari 0.70. \\
Sehingga seluruh variabel dapat dikatakan \\
reliable.
\end{tabular}

\section{AVE (Average Variance Extracted)}

Setiap variabel akan dinyatakan reliable apabila nilai AVE lebih besar dari 0,50 . Setelah dilakukan pengolahan data, terlihat nilai AVE dari setiap variabel bisa dilihat pada tabel 6 berikut ini.

Tabel 6. Nilai AVE Variabel

\begin{tabular}{lc}
\hline \multicolumn{1}{c}{ Variabel } & AVE \\
\hline Ketidakjelasan Peran & 0,756 \\
Kepuasan Kerja & 0,708 \\
Kinerja Pegawai & 0,749 \\
\hline
\end{tabular}

Sumber : Hasil Olahan SmartPLS 3.0, 2019

\section{Analisis R-Square}

Tabel 7. Nilai R-Square Model

\begin{tabular}{lc}
\hline \multicolumn{1}{c}{ Variabel } & $R$-Square \\
\hline $\begin{array}{l}\text { Ketidakjelasan peran } \\
\text { terhadap kepuasan kerja }\end{array}$ & 0,105 \\
$\begin{array}{l}\text { Ketidakjelasan peran dan } \\
\text { kepuasan kerja terhadap } \\
\text { kinerja }\end{array}$ & 0,503 \\
Sumber : Hasil Olahan SmartPLS 3.0, 2019 \\
Pada tabel 7 terlihat pengaruh \\
ketidakjelasan peran terhadap kepuasan kerja
\end{tabular}


menunjukkan nilai R-Square sebesar 0,105 dan bisa diinterpretasikan bahwa variabel kepuasan kerja mampu dijelaskan oleh variabel ketidakjelasan peran dan kepuasan kerja sebesar $10,5 \%$ sedangkan variabelvariabel lain yang tidak termasuk dalam penelitian ini mampu menjelaskan kepuasan kerja pada Puskesmas di Kota Padang Panjang sebesar $89,5 \%$. Hal ini menunjukkan bahwa ketidakjelasan peran memiliki pengaruh yang kecil terhadap kepuasan kerja.

Pengaruh ketidakjelasan peran dan kepuasan kerja terhadap kinerja pegawai menunjukkan nilai R-Square sebesar 0,503, maka dapat di interpretasikan bahwa variabel kinerja pegawai dapat dijelaskan oleh variabel ketidakjelasan peran dan kepuasan kerja sebesar 50,3\% sedangkan variabel-variabel lain yang tidak termasuk pada penelitian ini mampu menjelaskan kinerja pegawai pada Puskesmas di Kota Padang Panjang sebesar $49,7 \%$.

\section{Pembahasan Hasil Penelitian}

Tabel 8. Hasil Path Coefficients

\begin{tabular}{|c|c|c|c|}
\hline $\begin{array}{c}\text { Hubungan } \\
\text { antar Variabel }\end{array}$ & Koef. & T-Stat & Keterangan \\
\hline Ketidakjelasan & & & \\
\hline $\begin{array}{l}\text { Peran -> } \\
\text { Kinerja } \\
\text { Pegawai }\end{array}$ & $-0,389$ & 5,087 & $\begin{array}{c}\geq 1,96 \\
\text { (Signifikan) } \\
\text { H1 diterima }\end{array}$ \\
\hline Ketidakjelasan & & & \\
\hline $\begin{array}{l}\text { Peran -> } \\
\text { Kepuasan } \\
\text { Kerja }\end{array}$ & $-0,317$ & 3,160 & $\begin{array}{c}\geq 1,96 \\
\text { (Signifikan) } \\
\text { H2 diterima }\end{array}$ \\
\hline Kepuasan & & & \\
\hline $\begin{array}{l}\text { Kerja -> } \\
\text { Kinerja } \\
\text { Pegawai } \\
\end{array}$ & 0,469 & 6,885 & $\begin{array}{c}\geq 1,96 \\
\text { (Signifikan) } \\
\text { H3 diterima }\end{array}$ \\
\hline
\end{tabular}

Sumber : Hasil Olahan SmartPLS 3.0, 2019

Berdasarkan tabel 8 terlihat bahwa besarnya nilai T-Statistics pengaruh ketidakjelasan peran terhadap kinerja pegawai sebesar $5,087 \geq 1.96$. Hal tersebut menunjukkan bahwa terdapat pengaruh yang signifikan pada variabel ketidakjelasan peran terhadap kinerja pegawai. Sedangkan nilai koefisien yaitu sebesar -0,389. Koefisien tersebut bernilai negatif yang berarti apabila semakin tinggi ketidakjelasan peran maka akan semakin rendah pula kinerja pegawai.

Besarnya nilai T-Statistics pengaruh ketidakjelasan peran terhadap kepuasan kerja sebesar $3,160 \geq 1.96$. Hal ini menunjukkan bahwa ada pengaruh yang signifikan pada variabel ketidakjelasan peran terhadap kepuasan kerja. Sedangkan nilai koefisien sebesar -0,317. Koefisien tersebut memiliki nilai negatif yang artinya apabila ketidakjelasan peran semakin tinggi maka kepuasan kerja akan semakin rendah.

Adapun nilai T-Statistics dari pengaruh kepuasan kerja terhadap kinerja pegawai sebesar $6,885 \geq 1,96$. Hal ini berarti terdapat pengaruh yang signifikan pada variabel kepuasan kerja terhadap kinerja pegawai. Sedangkan nilai koefisien sebesar 0,469 . Koefisien tersebut bernilai positif yang artinya semakin tinggi kepuasan kerja maka semakin tinggi pula kinerja pegawai, begitu juga sebaliknya.

Tabel 9. Pengaruh Tidak Langsung

\begin{tabular}{lccc}
\hline $\begin{array}{c}\text { Hubungan } \\
\text { antar } \\
\text { Variabel }\end{array}$ & $\begin{array}{c}\text { Original } \\
\text { Sample }\end{array}$ & T-Stat & Keterangan \\
\hline $\begin{array}{l}\text { Ketidakjelas } \\
\text { an Peran }\end{array}$ & & & \\
$\begin{array}{l}\rightarrow \text { Kepuasan } \\
\text { Kerja-> } \\
\text { kinerja }\end{array}$ & $-0,149$ & 2,665 & $\begin{array}{c}\geq 1,96 \\
\text { (Signifikan) }\end{array}$ \\
pegawai & & & H4 diterima \\
Sumber:Hasil Olahan SmartPLS 3.0, 2019
\end{tabular}

Sumber : Hasil Olahan SmartPLS 3.0, 2019

Tabel 9 menunjukkan dimana besar koefisien pada pengaruh ketidakjelasan peran terhadap kinerja pegawai yang dimediasi kepuasan kerja sebesar -0,149 yang memiliki makna negatif dan signifikan pada 5\% (nilai t hitung $\geq 1.96$ ). Sehingga, dapat disimpulkan bahwa ketidakjelasan peran berpengaruh secara tidak langsung terhadap Kinerja pegawai melalui kepuasan kerja. Dapat dikatakan bahwa kepuasan kerja sebagai variabel yang memediasi pengaruh antara ketidakjelasan peran terhadap kinerja pegawai pada Puskesmas di Kota Padang Panjang dengan sifat competitive partial mediation. 
Sifat mediasi ini menjelaskan bahwa ketidakjelasan peran pengaruh negatifnya akan berkurang ketika melalui kepuasan kerja. Karena jika langsung kepada kinerja pegawai dibandingkan melalui mediasi, lebih besar nilai pengaruhnya yaitu -0.389 dibandingkan secara tidak langsung sebesar 0.149. Kepuasan kerja memediasi secara parsial dikarenakan setelah perhitungan nilai VAF didapatkan nilai pengaruh sebesar $27,7 \%$.

\section{Kesimpulan}

Berdasar hasil analisa, dapat disimpulkan beberapa hal: 1) Terdapat pengaruh negatif dan signifikan antara ketidakjelasan peran terhadap kinerja pegawai Puskesmas di Kota Padang Panjang, 2) Terdapat pengaruh negatif dan signfikan antara ketidakjelasan peran terhadap kepuasan kerja pegawai Puskesmas di Kota Padang Panjang, 3) Terdapat pengaruh positif dan signifikan antara kepuasan kerja terhadap kinerja pegawai Puskesmas di Kota Padang Panjang, dan 4) Terdapat pengaruh kepuasan kerja sebagai variabel pemediasi antara ketidakjelasan peran terhadap kinerja pegawai Puskesmas di Kota Padang Panjang. Kepuasan kerja memediasi secara parsial antara ketidakjelasan peran terhadap kinerja pegawai Puskesmas di Kota Padang Panjang.

\section{DAFTAR PUSTAKA}

Fanani, Z., Hanif, R. A., \& Subroto, B. (2008). Pengaruh Struktur Audit, Konflik Peran, dan Ketidakjelasan Peran terhadap Kinerja Auditor. Jurnal Akuntansi dan Keuangan Indonesia, 5(2), 139-155.

Gibson, J. L., Ivancevich, J. M., Donnelly, J. H., \& Konopaske, R. (2012). Organizations Behavior, Structure, Processes Fourteenth Edition. New York: McGraw-Hill.

Khattak, A., Urooj, S. F., Khattak, J., \& Iqbal, N. (2011). Impact of Role Ambiguity on Job Satisfaction: Mediating Role of Job Stress. International Journal of Academic Research in Business and Social Sciences, 1(3), 516-531.
Koopmans, L., Bernaards, C., Hildebrandt, V., Buuren, S., Beek, A. J., \& Vet, H. C. (2014). Development of an Individual Work Performance Questionnaire. International Journal of Productivity and Performance Management. (62)1, 6-28.

Mariam, R. (2009). Pengaruh Gaya Kepemimpinan dan Budaya Organisasi terhadap Kinerja Karyawan melalui Kepuasan Kerja Karyawan sebagai Variabel Intervening. Universitas Diponegoro. Mathis, R. L., \& Jackson, J. H. (2008). Human Resource Management Twelfth Edition. USA: Thomson South-Western.

Palomino, M. N., \& Frezatti, F. (2016). Role Conflict, Role Ambiguity and Job Satisfaction: Perceptions of the Brazilian Controllers. R.Adm, Sao Paulo, 51( 2), 165-181.

Peraturan Menteri Kesehatan Nomor 75

Tahun 2014 tentang Pusat Kesehatan Masyarakat Pasal 1 Ayat 2, 2014.

Robbins, S. P., \& Judge, T. A. (2013). Organizational Behavior. USA: Pearson Education Inc.

Robbins, S. P., \& Judge, T. A. (2015). Perilaku Organisasi. Jakarta: Salemba Empat.

Sekaran, U., \& Bougie, R. (2016). Research Methods for Business. United Kingdom: John Wiley \& Ons Ltd. 